\title{
US warms to carbon sequestration research
}

San Diego

The US Department of Energy (DoE) is investigating whether the sequestration of atmospheric carbon dioxide in oceanic or terrestrial ecosystems might be an effective way of reducing global warming.

The department has given $\$ 9$ million for three years to two research centres - one each to study the ocean and land - involving scientists from various institutions. Earlier this month, the DoE solicited proposals for $\$ 18$ million in carbon sequestration research, with another solicitation expected soon (see www.fetc.doe.gov/business/solicit).

The budding research initiative - which will eventually require far more funds - is drawing together scientists from a variety of disciplines to study cost-effective and environmentally safe methods for the separation, capture and sequestration of the carbon dioxide emitted from fossil fuel. For instance, it might be possible to draw carbon dioxide from the emissions of a power plant, treat it and inject it deep into the ocean for storage.

The research projects are developing in a complex political climate where there is a broad consensus on the need to reduce emissions of greenhouse gases, but varying views on the most cost-effective way to do this.

Some nations, such as Japan and Norway, have aggressively pursued carbon sequestration research. But the United States has funded little research in this area, partly because of political sensitivities. Industry, which depends on fossil fuels, and its congressional advocates feared added costs, while some environmentalists felt carbon sequestration would not curb the burning of fossil fuels.

Last week, the DoE held a workshop bringing together scientists, industry, environmentalists and government officials to seek guidance for "a research road map for practical carbon sequestration technologies", and to seek comment on its recently released draft white paper, Carbon Sequestration-State of the Science.

Scientists attending the two-day workshop in Maryland described it as an encouraging exercise that showed new cooperation among disparate parties. But they also said that a shortage of data means it will be decades before some new forms of sequestration find large-scale applications.

"There is so much we don't know," says Howard Herzog, a chemical engineer at the Massachusetts Institute of Technology's energy laboratory, "but if we don't do the groundwork now, we won't be ready".

With terrestrial sequestration, carbon dioxide emissions would be pumped into geological formations or old oil wells, reduced by farming techniques (such as eliminating deep ploughing), or offset by forestry procedures such as planting more

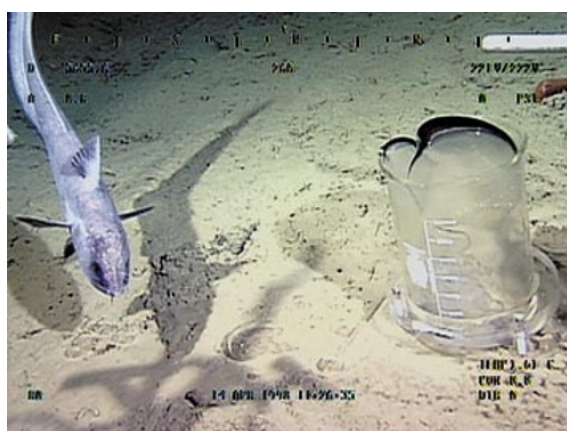

Deep thought: the effects of liquefied carbon dioxide on the ocean environment are already being studied by the University of Hawaii.

trees. Small-scale applications of these methods are already being applied in some countries, mostly without controversy.

In contrast, ocean storage of carbon dioxide is seen as having great potential because of the vast areas available; but environmental issues make it a sensitive alternative. Injecting carbon dioxide may change the ocean chemistry, possibly with harmful ecological consequences.

It is these aspects of carbon storage that scientists want to study. Next month, the UK-based Environment Council will hold a workshop in New York to explore whether the injection of carbon dioxide into the ocean is "a robust environmental management strategy". In May, the organization held a similar workshop in London.

With ocean sequestration, carbon dioxide would be liquefied and then pumped into the depths, where huge amounts of carbon already exist in forms such as carbonic acid or carbonate.

Dispersing carbon dioxide in the ocean is also being considered, but this may be even more controversial, because of concerns about more widespread ecological damage.

"We are being quite cautious," says Jim Bishop, a marine chemist at the Lawrence Berkeley National Laboratory who is a codirector of the DoE's new Center for Research on Ocean Carbon Sequestration. "Before we pump carbon dioxide into the sea, we need to better understand how it will work."

To that end, a team of scientists in Hawaii is preparing to conduct the most extensive experiment to date on injecting liquefied carbon dioxide into the deep ocean. The \$5million, four-year project is being funded mostly by Japan, with assistance from the United States, Norway and Canada. Australia is also expected to join.

Stephen Masutani, a mechanical engineer at the University of Hawaii who is one of the project's leaders, says the plan is to inject liquefied carbon dioxide 900 metres deep off the Kona coast in the summer of 2001.

The injection will use a small, removable pipe laid into the ocean from the Hawaii Natural Energy Laboratory. A remotely operated, mobile platform will monitor carbon dioxide dispersal at the injection site. "The idea is to obtain data for predictive models," said Masutani. "We want to see what the changes in the sea chemistry are."

But, despite more than two years of planning and laboratory work, Masutani says the experiment is under scrutiny from local environmental groups concerned about the impact on sea life and water chemistry.

The Hawaii team is spending considerable funds on explaining the experiment. If a full environmental impact statement is required, says Masutani, it would delay the experiment beyond the funding period set by Japan, possibly scuppering it. Decisions on the environmental assessment needed are expected in the next few months. Rex Dalton

\section{German museums face cuts}

\section{Munich}

Publicly funded research at Germany's six largest science and history museums including the Deutsches Museum in Munich - is to be cut next year by at least 7.5 per cent.

Areas likely to be immediately affected at the Munich museum include its efforts to promote the public understanding of science, for which it has recently taken on responsibility for nationwide coordination.

Some of the biological research at the Zoological Research Institute and Museum Alexander Koenig in Bonn would be "paralysed" by the threatened cuts, according to Michael Schmitt, a biological researcher there. "It would mean the end of my research project on the phylogeny of Chrysomelidae [leaf beetles]," he says.

The museums' research departments form part of the Wissenschaftsgemeinschaft Gottfried Wilhelm Leibniz (WGL) formerly called the 'blue list' - a loose association of 82 research and service institutes that makes up Germany's 'fourth pillar' of non-university research.

The WGL is funded equally by the federal government and Germany's 16 Länder (states), as are the Max Planck Society (MPS) and the university funding organization, the Deutsche Forschungsgemeinschaft (DFG).

The MPS and DFG will see their budgets 


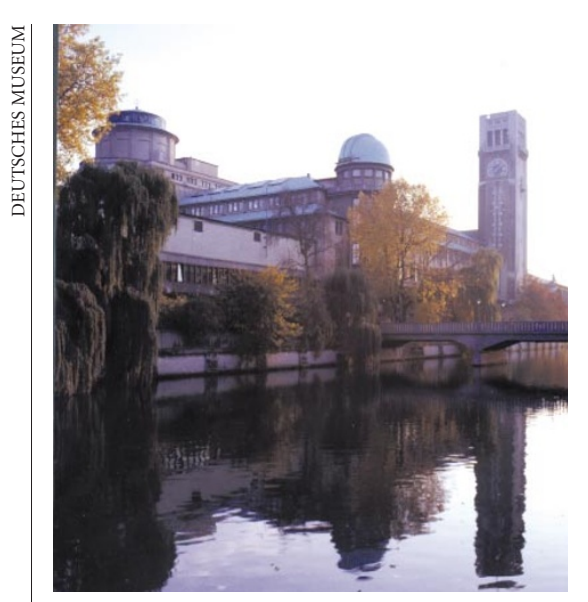

Shrinking asset: Munich’s Deutsches Museum.

increased next year. But the science museums are not being exempted from an overall decrease of DM30 billion ( $\$ 16$ million) in public spending imposed by finance minister Hans Eichel to reduce the national debt.

"This is a clear [act of] discrimination against the WGL, and science museums in particular," says an official of the Bund-Länder-Kommission für Bildungsplanung und Forschungsförderung (BLK), which coordinates regional and federal research policies.

The WGL already faces the problem that responsibility for funding its institutes is spread over ten ministries. As for the science museums, funding responsibility shifted last year from the Ministry of the Interior to the new Ministry of Cultural and Media Affairs.

Culture minister Michael Naumann has announced that the cuts will be imposed equally across all spending areas of his ministry. With a relatively small portfolio of DM1.7 billion, Naumann says that he cannot prioritize some areas by excluding them from the cuts. In contrast, the research ministry has been able to respond more flexibly by shifting its priorities.

Research costing DM46.2 million is being carried out at the six science museums this year. Germany's science council, the Wissenschaftsrat, has confirmed the high quality of the museums' research departments, and recommended that the proportion of research to other museum activities should be maintained.

But the 7.5 per cent cut will hit the museums hard. "The cuts come at a time when we had been about to expand our activities," says Helmuth Trischler, director of science and vice-directorgeneral of the Deutsches Museum. "As a consequence, we will not be able to do what we intended to." Quirin Schiermeier

\section{US university finds use for Air Force research reactor}

\section{San Diego}

The University of California (UC) at Davis received approval last week to acquire a research nuclear reactor, up to now used by the US Air Force (USAF), for use in studies in engineering, materials science, agriculture and medical therapies.

The reactor, located at the USAF's McClellan Air Force Base, about 20 miles from the university, was built in 1990, making it the youngest of the TRIGA (Training, Research, Isotopes, General Atomics) class of research reactors which are no longer being built in the United States.

The reactor will form the core of a developing research programme at Davis, which officials say will become more important in future years as older research reactors are decommissioned and not replaced.

"Eventually, UC Davis may be the only show around" for research reactors, says Kevin M. Smith, UC Davis' vice-chancellor for research. Officials say that research reactors are difficult to build because of increasing costs, the extensive environmental assessment process required and community opposition.

Under terms of the agreement approved last week by the UC Board of Regents, the reactor must be used at least 51 per cent of the time for research; the remainder of the time it can be used for revenue-producing commercial work, which university officials hope will cover some of its operational costs.

The Air Force has been using the reactor for neutron radiography to detect hidden cracks and defects in aircraft wings. Some similar work may continue as UC Davis builds up its reactor-based research programme.

After a competitive selection process, the university has appointed Science Applications International Corp. (SAIC) of San Diego as the reactor's operator. Most employees now working at the site will be hired by SAIC.

The US Department of Energy is providing $\$ 8$ million to fund research and operational costs for the reactor for the next four years. And the federal government is giving \$17.6 million for the future decommissioning of the reactor, expected in about 30 years.

As UC Davis develops a programme of teaching and research around its reactor, officials plan to collaborate with UC Berkeley's department of nuclear engineering, and with UC Irvine.

Rex Dalton

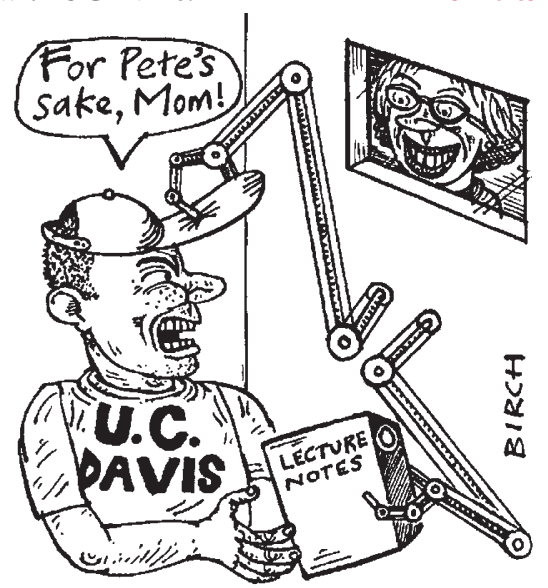

\section{UK universities look to enterprise}

\section{Sheffield}

Eight UK universities are to set up 'centres of enterprise' to exploit their research and transfer ideas to the private sector. Steven Byers, the Secretary of State for Trade and Industry, announced the news last week at the British Association for the Advancement of Science's annual Festival of Science.

One of the responsibilities of the centres,

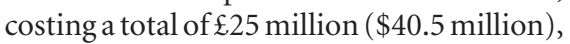
will be to incorporate the teaching of enterprise into the universities' curricula, equipping scientists and engineers with entrepreneurial skills. The government hopes the centres will play a key role in regional development, and wants them to link up with local companies.

Byers also announced the extension of the network of Faraday Partnerships, which aim to link science and business in specific areas of technology by bringing together consortia of independent research organizations, universities, businesses and financiers. Four new partnerships, with a budget of $\mathfrak{E} 8.8$ million, were announced. Consortia are invited to propose new topics in their bids. "We want your ideas, we want to see partnerships strengthening industry clusters in their localities," said Byers.

Byers announced additional funding for the four existing Faraday Partnerships. He said this was because the previous government had underfunded the centres, and added that the extra support would allow them to restructure their 'industry-facing' activities.
NatashaLoder 